\title{
FACTORS THAT INFLUENCE OF SUPPLY AND DEMAND OF CRYSTAL SUGAR IN INDONESIA
}

\author{
Wahib Muhaimin Abdul*, Chalimatus Sa'diyah, Hardana Andrean Eka \\ Faculty of Agriculture, University of Brawijaya, Malang, Indonesia \\ *E-mail: awmuhaimin@gmail.com
}

\begin{abstract}
The purposes of this research were to analyze the factors affecting supply and demand of crystal sugar, and the elasticity of supply and demand of crystal sugar. The results showed that the productivity of sugar cane has a value (R2) of 0,309 . The interest rate, wage, and fertilizer price were significantly influenced to sugarcane productivity and negative value. Land area has a value (R2) of 0,511 . The price of sugarcane has a significant effect on the land area and positive value. Sugar productivity has a value (R2) of 0,209. Quantity of sugar cane production has significantly affected the land area and positive value. The demand for sugar has a value (R2) of 0.702 . The sugar price and demand of the previous year had a significant and negative effect on sugar prices and positive for sugar demand for the previous year. Domestic sugar price has a value (R2) of 0,844 . World sugar price, nominal rate of protection, exchange rate significantly influences sugar price and positive. The import of sugar in Indonesia is worth (R2) of 0,846. Sugar imports in the previous year had a significant effect on sugar prices and positive. Domestic sugar demand and nominal rate of protection were an elastic level of 2,279 and 1,273 .
\end{abstract}

\section{KEY WORDS}

Forcasting, import, crystal sugar, demand sugar, Indonesia.

Sugar is one of commodities that plays a big role in agricultural sector especially sub plantation sector in indonesia.Sugar is also one of basic needs and the source of calories relatively inexpensive (a body of agricultural research, 2005). The score at sugar as an ingredient of sweetening main cannot replaced by other substances which used both by households and industry food and drink.

A lot of factors affect the condition of a setback sugar industry in indonesia. In addition to the decline in the level of efficiency in the farming business and sugar factory, a variety of factors such as the policy of the government also influential significantly against a setback of the sugar industry in indonesia (Susilo, 2005). There was a policy import sugar raised fears the government will import sugar high, which is seen as the threat to food independence. Food independence is an important thing in the developing countries with a population of great with purchasing power of the community is relatively low like Indonesia. The stability of the normal price of sugar in the domestic market at a rate that benefits producers (sugar industry) and appropriate for consumers, is a thing that matters in order to ensure the survival of the sugar industry and prompted the national sugar confection. The demand of sugar could be met as one of essential commodities the community (Churrmen, 2001).

Production sugar domestic less able to fulfill the community so the shortages have to covered sugar imports continue to menigkat from year to year since 1990.A period of the year 1991-2001, sugar industry indonesia is a tendency volume import with the increasing.A limitation on imports sugar needs to be done to maintain the sustainability of the industry sugar while keeping wealth who are reached by the community.

Import activities were included in the supply area of crystal sugar so that it must be systematically analyzed from the supply side. Offer of course affects the supply of sugar crystal in Indonesia, so it can control the flow of imported sugar into the territory of Indonesia. Therefore, it is necessary to analyze the factors that can influence the amount of sugar import as well as analyze the elasticity of imports. This analysis activity can be used as the initial basis to forecast the import of sugar in Indonesia in the future. The purpose of this 
study was to analyze the factors that influence supply and demand of crystal sugar and to analyze the elasticity of supply and demand of crystal sugar.

\section{METHODS OF RESEARCH}

Type and data source of this research is secondary data obtained from related institution. Secondary data represents data obtained from a literature study and organizations relevant research. Secondary data needed is the results of the study before relevant to furnish this research. The data obtained by conducting documentation and search information from agencies. Among others office of agriculture, bureau statistic center, the board sugar indonesia, the directorate general plantation site and FAO site, USDA site, site word bank and various literature that support the preparation of this research. The kind of data that used was the data the time from year 1985-2013.

Analysis of research data using qualitative and quantitative analysis. Quantitative analysis in this research use simultaneous equation model. Simultaneous system model of simultaneous equation in structural form that is identified more used 2 SLS method. If all model equations are overidentified, then this model is most suitable to use. So in this research will be used method 2 SLS which expected result can describe actual condition according to data processed.

Model Identification. Identification is needed to find out how to solve the existing simultaneous equation system or whether a system of simultaneous equations is solved or not. There are three identification problems in the simultaneous equations, where each of the identification problems can know what method is appropriate to solve a system of simultaneous equations encountered. The three problems are: underidentified, exactly identified, and overidentified. Identify the model using order condition with the following formula:

$$
\begin{gathered}
(\mathrm{K}-\mathrm{k})=(\mathrm{m}-1): \text { exactlyidentified } \\
(\mathrm{K}-\mathrm{k})>(\mathrm{m}-1): \text { overidentified } \\
(\mathrm{K}-\mathrm{k})<(\mathrm{m}-1): \text { underidentified }
\end{gathered}
$$

Where: $\mathrm{K}=$ The number of predetermined variables includes current exogenous variables in the model; $\mathrm{k}=$ The number of predetermined variables in a given structural equation; $\mathrm{m}=$ The amount of current is endogenous in the model.

The following will be done calculation in accordance with the order condition of the equations used in this study:

$$
\begin{aligned}
& Q t=L t^{*} Y t \\
& Y t=a+a_{1} L t+a_{2} P b i t+a_{3} P P u k+a_{4} W+a_{5} i \\
& L t=b+b_{1} P a+b_{2} P j+b_{3} I+b_{4} P g+b_{5} P P u k+b_{6} P b i t \\
& Q g=r t{ }^{*} Q t \\
& Y g=c+c_{1} r t+c_{2} Q t \\
& Q s=Q g+M g p \\
& M g p=f+f_{1} P w+f_{2} E R+f_{3} Q d+f_{4} M g p t-1 \\
& Q d=d+d_{1} P g+d_{2} P o p+d_{3} I n+d_{4} \text { Qdt-1 }_{1} \\
& P g=e+e_{1} P w+e_{2} E R+e_{3} N r p+e
\end{aligned}
$$

Where:

Qt = Quantity of sugar cane production;

$\mathrm{Lt}=$ Sugar Cane Area;

$\mathrm{Yt}=$ Sugar cane Productivity;

PPuk = Fertilizer Price;

Pbit = Seed Price;

$\mathrm{W}=$ Wages;

$\mathrm{i}=$ Loan interest degree;

$\mathrm{Pg}=$ Sugar price; 


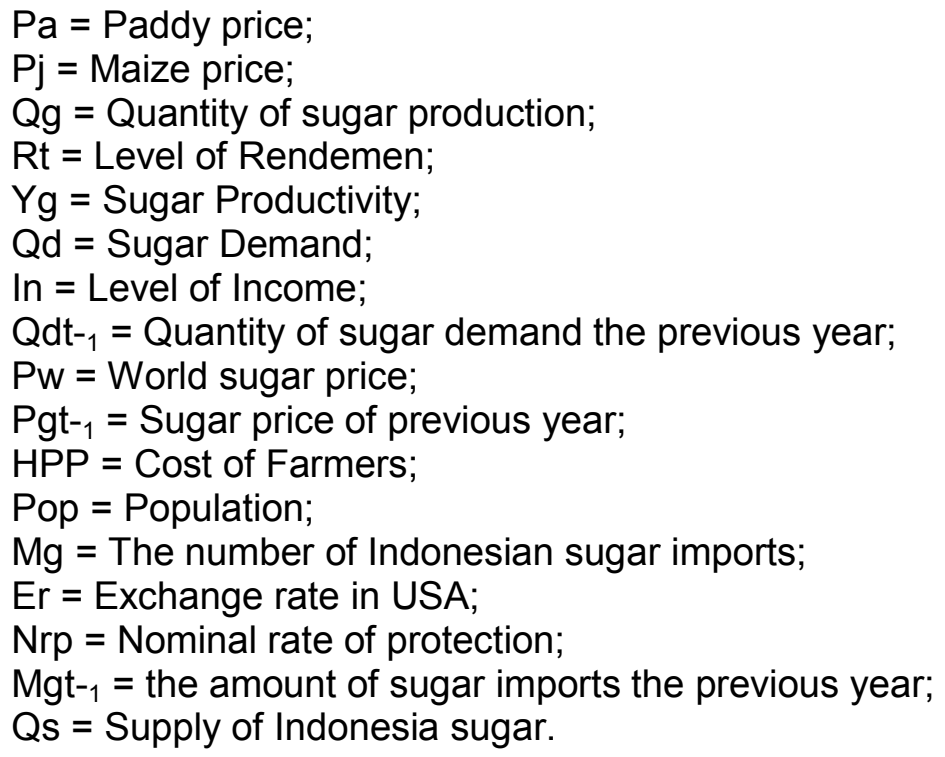

Based on the above equation it can be identified that the total number of variables used in the above equation amounted to 25 . The calculation is only done on the structural equation, so the number of equations is 6 . The following table 1 will show the results of calculations.

Table 1 - Result of order condition calculation

\begin{tabular}{|c|c|c|c|c|c|}
\hline Equation & $\mathrm{K}$ & $\mathrm{K}$ & $\mathrm{M}$ & Calculation & Result \\
\hline $\mathrm{Yt}$ & 25 & 5 & 6 & $25-5>6-1$ & Over Identified \\
\hline $\mathrm{Lt}$ & 25 & 6 & 6 & $25-6>6-1$ & Over Identified \\
\hline $\mathrm{Yg}$ & 25 & 2 & 6 & $25-2>6-1$ & Over Identified \\
\hline $\mathrm{Qd}$ & 25 & 4 & 6 & $25-4>6-1$ & Over Identified \\
\hline $\mathrm{Pg}$ & 25 & 5 & 6 & $25-5>6-1$ & Over Identified \\
\hline $\mathrm{Mg}$ & 25 & 4 & 6 & $25-4>6-1$ & Over Identified \\
\hline
\end{tabular}

Model Estimation. The model estimation uses the 2SLS method which shows that the model is Over Identified. Analyzer used for process completion simultaneous equation model using software SAS 9.1.3.

Statistic testing. This test is expected to know which exogenous variables that affect the endogenous variables, either together or partially. For that required testing consisting of t-statistical test, $F$ test and $R^{2}$ test. Other statistical tests need to be done before testing to make sure the data used is appropriate especially for secondary data and time series ie stationary tests (gaynor and Patrick, 1994).

\section{RESULTS AND DISCUSSION}

Information from in chapter before, the model formulated is linear model simultaneous equations; with the methods two stage least aquares method (2SLS). This section is will be explained the results of research has diperleh begins with presentation of equation his behavior based on a sign and magnitude, the coefficients determination, statistical of $F$ test and $T$ test.

According sa'diyah (2014) Estimation model done with use some help software SAS. Next phase that is testing statistic of the estimation results which includes $T$ test, $F$ test and $\mathrm{R}^{2}$ in each equation was answering research objectives the first namely know what factors affecting economic crystal sugar in indonesia. In addition research objectives both to know elasticity short-term can also directly known of the size of variable parameter measured.

The following is the results of the analysis of the equation first to explained through table 2 showing equation strujtural of all of our productivity of the sugar cane by factors 
affecting the area of land, the price of fertilizer, wages and interest rates based on the data time series start know 1985-2013.

Table 2 - The results of the analysis productivity cane

\begin{tabular}{|c|c|c|}
\hline Variable & Coefficient & $\operatorname{Pr}>|\mathrm{t}|$ \\
\hline Intercept & 2.255294 & 0.0016 \\
\hline Lt & 0.079514 & 0.5048 \\
\hline PPuk & $-0.105759^{*}$ & 0.0557 \\
\hline W & $-0.20823^{*}$ & 0.0653 \\
\hline I & $-0.20823^{* *}$ & 0.0653 \\
\hline
\end{tabular}

R-Square $=0.30928$

$\mathrm{F}=2.69$

F tabel $\alpha 5 \%=2,78$

Durbin Watson $=1.807961$

*** significant on a $1 \%$

** significant on a $5 \%$

*significant on $10 \%$

Based on 2SLS analyzis result for table 1, got equation as follow:

$$
Y t=2.255294+0.079514 \text { Lt -0.105759PPuk - 0.20823W- }-0.20823 I+e
$$

Based on table above known productivity cane it has value $\left(R^{2}\right)$ as much as 0,309 shows that $30,9 \%$ equation cane productivity in indonesia can be explained by variable land area, price of fertilizer, wages and interest rates while $69,1 \%$ the rest explained other variables that aren $t$ pursuing. Interest rates, wages and the price of fertilizer is influence significantly to productivity cane and was negative.

Table 3 - Result of Land Area Analysis

\begin{tabular}{|c|c|c|}
\hline Variable & Coefficient & Pr> $|t|$ \\
\hline Constanta & 4.309922 & 0.0016 \\
\hline $\mathrm{Pa}$ & 0.00291 & 0.9884 \\
\hline $\mathrm{Pj}$ & 0.170420 & 0.3548 \\
\hline $\mathrm{Pg}$ & 0.242534 & 0.0695 \\
\hline $\mathrm{I}$ & -0.12728 & 0.3324 \\
\hline PPuk & 0.016894 & 0.5622 \\
\hline
\end{tabular}

R-Square $=0.51121$

$\mathrm{F}=4.81$

F tabel $\alpha 5 \%=2,78$

Durbin Watson $=0.603793$

*** significant on $\alpha 1 \%$

** significant on a $5 \%$

*significant on $10 \%$

Based on 2SLS result analysis on table 2 above, got equation as follow:

$$
L t=4.309922-0.00291 \mathrm{~Pa}-0.170420 \mathrm{Pj}+0.242534 \mathrm{Pg}-0.12728 \mathrm{I}+0.016894 \mathrm{PPuk}+\mathrm{e}
$$

Based on table above known land area it has value $\left(R^{2}\right)$ as much as 0.51121 shows that $51,1 \%$ equation land area in indonesia can be explained by variable rice price, corn price, sugar price, interest rates and fertilizer price while $48,9 \%$ the rest explained other variables that aren t pursuing. The price of sugar cane influence significantly to of land area and is positive, while variable of rice price, corn price, interest rates, and fertilizer price not had have real impact on the land. 
Table 4 - Result of Sugar Productivity

\begin{tabular}{|c|c|c|}
\hline Variable & Coefficient & Pr> |t| \\
\hline Constanta & 2.155332 & 0.2244 \\
\hline rt & 0.012061 & 0.9878 \\
\hline Qt & $0.012061^{* *}$ & 0.0146 \\
\hline
\end{tabular}

R-Square $=0.20922$

$\mathrm{F}=3.44$

$\mathrm{F}$ tabel a $5 \%=2,78$

Durbin Watson $=0.252783$

*** significant on a $1 \%$

** significant on $\alpha 5 \%$

* significant on $10 \%$

Based on 2SLS result analysis on table 3 above, got equation as follow:

$$
Y g=2.155332+0.012061 r t+0.012061 Q t+e
$$

Based on table above known area of land it has value $\left(R^{2}\right)$ as much as 0.20922 shows that the 20.9 percent equation productivity sugar in indonesia can be explained by variable rendemen and production cane while 79.1 percent of the explained other variables that aren $t$ pursuing. The volume of production cane influence significantly to productivity cane and is positive, while variable rendemen not had have real impact on productivity sugar.

Table 5 - Result of Sugar Demand Analysis

\begin{tabular}{|c|c|c|}
\hline Variable & Coefficient & Pr> $|\mathrm{t}|$ \\
\hline constanta & 3.410803 & 0.2968 \\
\hline Pg & $-0.16359^{*}$ & 0.988 \\
\hline Pop & 0.08847 & 0.8288 \\
\hline In & 0.058484 & 0.6633 \\
\hline Qdt-1 & $0.643324^{\star * *}$ & 0.0001 \\
\hline
\end{tabular}

R-Square $=0.70241$

$\mathrm{F}=14.16$

F tabel a $5 \%=2.78$

Durbin Watson $=1.988423$

*** significant on a $1 \%$

** significant on $\alpha 5 \%$

*significant on $10 \%$

According of 2SLS result analysis on table above, got equation as follow:

$$
Q d=3.410803-0.16359 P g+0.08847 \text { Pop }+0.054848 \text { In + } 0.633324 \text { Qdt-1 }+e
$$

Table 6 - Result of Sugar Price Analysis

\begin{tabular}{|c|c|c|}
\hline Variable & Coefficient & $\operatorname{Pr}>|t|$ \\
\hline Constanta & 0.271149 & 0.5619 \\
\hline Pw & $0.665334^{\star \star *}$ & 0.0001 \\
\hline Er & $0.719725^{\star * *}$ & 0.0059 \\
\hline Nrp & $2.279440^{\star * *}$ & 0.0001 \\
\hline HPP & 0.113093 & 0.3006 \\
\hline Pgt-1 & 0.062882 & 0.5363 \\
\hline
\end{tabular}

R-Square $=0.84390$

$\mathrm{F}=24.87$

F tabel $\alpha 5 \%=2.78$

Durbin Watson $=1.946741$

*** significant on a $1 \%$

** significant on a $5 \%$

*significant on $10 \%$ 
Based on table above known land area it has value $\left(R^{2}\right)$ as much as 0.70241 shows that $70,2 \%$ equation demand sugar in indonesia can be explained by variable sugar price, population, income, demand sugar years former while $29,8 \%$ of the explained other variables that aren't pursuing. Sugar price influence significantly and was in nature negative, while demand sugar the previous year influence significantly and negative to productivity cane and is positive to demand sugar. To variable the population and penapatan not influence significantly to demand sugar.

Based on 2SLS result analysis on table above, got equation as follow:

$$
P g=0.271149+0.665334 \mathrm{Pw}+0.719725 \mathrm{Er}+2.279440 \mathrm{Nrp}+0.113093 \mathrm{HPP}+0.062882 \mathrm{Pgt}_{-1}+\mathrm{e}
$$

Based on table above known sugar price domestic it has value $\left(R^{2}\right)$ as much as 0.84390 shows that $84.3 \%$ equation sugar price in indonesia can be explained by variable sugar price the world, the exchange rate, nominal rate of protection, basic price farmers and sugar price the previous year while $15.7 \%$ of the described by other variables that tiak study. Sugar price the world, nominal rate of protection, the exchange rate influence significantly on the price of sugar and is positive. On the variables basic price farmers and sugar price years not previously influence significantly to domestic demand sugar price.

Table 7 - Result of Sugar Import Analysis

\begin{tabular}{|l|l|l|}
\hline Variable & Coefficient & Pr $|\mathrm{t}|$ \\
\hline constanta & -8.03120 & 0.3445 \\
\hline Pw & 0.579741 & 0.3023 \\
\hline ER & 0.072691 & 0.9746 \\
\hline Qd & 1.273201 & 0.3550 \\
\hline Mgt-1 & $0.673415^{\star * *}$ & 0.0001 \\
\hline
\end{tabular}

R-Square $=0.84628$

$\mathrm{F}=33.03$

F tabel a $5 \%=2.78$

Durbin Watson $=12.309193$

*** significant on a $1 \%$

** significant on a $5 \%$

*significant $10 \%$

Based of 2SLS result analysis on table above, got equation as follow:

$$
M g=-8.03120+0.579741 P w+0.072691 E R+1.273201 \mathrm{Qd}+0.673415 \mathrm{Mgt}-1+\mathrm{e}
$$

Based on table above known import sugar in indonesia to have the value of $\left(R^{2}\right)$ as much as 0.84628 shows that $84.6 \%$ equation import sugar in indonesia can be explained by variable sugar price the world, the exchange rate, demand sugar, import sugar the previous year while $15,4 \%$ of the described by other variables that aren't pursuing. Import sugar the previous year influence significantly to import sugar and is positive.Variable sugar price the world, the exchange rate, demand sugar not influence significantly to import sugar.

Domestic demand sugar and a nominal rate of protection, lies on the level elastic with a elasticity of 2.279440 and 1.273201 . This indicates that every happened an increase in demand sugar of $1 \mathrm{~kg}$ will increase import sugar of $2.279440 \mathrm{~kg}$ and when been an increase in 1 percent for nominal rate of protection will improving the normal price of sugar IDR 1.273.201.

\section{CONCLUSION AND SUGGESTIONS}

Factors that affect supply and demand crystalline sugar in Indonesia consisting of the supply side, demand and prices as follows: 
Factors affecting demand and supply sugar crystals of the supply side is the price of fertilizer, wages, interest rates, sugar price domestic, production and imports sugar cane the previous year. The price of fertilizer, wages, and the normal price of sugar had have real impact and negative while production and imports sugar cane the previous year had have real impact and positive.

Factors that affect the supply and demand of crystal sugar from sides of demand is the demand for sugar in previous years and the price of domestic sugar, both the real and influential variables was negative.

Factors that affect the supply and demand of crystal sugar from sides of the price is the price of domestic sugar, sugar world prices, exchange rates and the nominal rate of protection, the overall variables that affect the price of real and has a positive effect.

Domestic demand sugar and a nominal rate of protection are on a level that elastic with an elasticity of 2.279440 and 1.273201 . The data indicates that each happened an increase in demand sugar of $1 \mathrm{~kg}$ will increase import sugar of $2.279440 \mathrm{~kg}$, while if there is an increase of eat nominal rate of protection will increase sugar price of IDR 1.273.201

Suggestion for government based on the research done that has been done maybe can be used in us consideration determine sugar policy expected can increase production of sugar cane and sugar in indonesia by reducing sukau the interest on the loan and give fertilizer subsidy, increased the price of the sugar thus farmers is interested in plant tebudan will increase productivity cane, when the price of sugar crystal up and the demand side crystal sugar will decline. The condition of being in balance with increased production of sugar domestic could decrease the number of import crystal sugar.

For researchers next should be able to investigation by the use of model research and instrument analysis more etail and complex that obtained model more detailed in describing import sugar based on berbegai kind of sugar imported as raw sugar, refined sugar or white sugar to to reflect demand imports in each type of sugar.

\section{REFERENCES}

1. Agriculture Research and Development Berau. (2005). Sugar Cane in Indonesia. Agriculture Berau. Jakarta.

2. Bernatonyte, D. Burksaitiene, D. \& Rimiene, K. (2013). Trade Specialization Pattern of Lithuania. Economics and Management: 2013. 18 (4).

3. Bernatonyte, D. \& Normantiene, A. (2009). Estimation of Trade Specialization: the Case of the Baltic States. Ekonomika-Engineering Economics (2).

4. Burger, K. Kameo, D. \& Sandee, H. (2001). Clustering of Small Agro-Processing Firms in Indonesia. International Food and Agribusiness Management Review, 2(3/4): 289-299.

5. Caporale, G. M. \& Sova, R. (2015). Trade Flows and Trade Specialisation: The Case of China. Working Paper No. 15-07.

6. Churmen, Imam. (2001). Save sugar industry in Indonesia. Millenium Publisher. Jakarta.

7. Dachliani, D. (2006). Demand of sugar import on 1980-2003 in Indonesia. (Thesis). Faculty of Economic. Diponegoro University. Semarang.

8. Delroy Anthony Armstrong.(2004). The Potential Impact of Trade Policychanges on Caribbean Sugar. B.S., Louisiana State University.

9. Dipl.-Ing. Dieter Bahndorf, Udo Kienle. (2004). World Market of Sugar and Sweeteners. OECD-FAO Agricultural Outlook 2016-2025, OECD Publishing, Paris.

10. Firmansyah, (2008). The Position of Competitiveness and Specialization Trading of Tealndonesia in Facing Globalization.Brawijaya. University. Malang.

11. Gaynor, P.E., and R.C. Kirk Patrick.(1994). Tome Series Modeling and Forecasting in Business and Economics. New York, Mc Graw hill.

12. Haley, Stephen.2013. World Raw Sugar Prices The Influence of Brazilian Costs of Production and World Surplus/ Deficit Measures. United States Department of Agriculture

13. Matsumura, Kanichiro.(2010). Demand and Supply Structure for Food in Asia. Sustainability 2011, 3, 363-395; doi:10.3390/su3020363. 
14. McConnell, Michael; Erik Dohlman; Stephen Haley. (2010). World Sugar Price Volatility Intensified by Market and Policy Factors.

15. McCormick, A. J. Watt, D. A. and Cramer, M. D.(2009). Supply and demand: sink regulation of sugar accumulation in sugarcane. Journal of Experimental Botany, Vol. 60, No. 2, pp. 357-364.

16. Rumánková, Lenka and Smutka, Luboš. (2013). Global Sugar Market - The Analysis Of Factors Influencing Supply and Demand. Volume LXI. No. 2, pp. 463-471.

17. Sa'diyah, C. (2014). Factors that influence of economic performance for crystal sugar in Indonesia. (Thesis). Faculty of Agriculture. University of Brawijaya. Malang.

18. Sinaga, N. (2006). Model Econometric Aplication. IPB Post Graduate. Bogor.

19. Susila, Wayan.R dan Bonar M. Sinaga. (2005). Analysis of Sugar Industry Policy in Indonesia. Jurnal Agro - Ekonomi Volume 23 No. 1, page 30-53.

20. Xue Xu and Hailong Xia.(2014). Analysis and Outlook of China's Sugar Industry Development. Proceedings of Selected Articles of 2013 World Agricultural Outlook. 